\title{
OCCURRENCE OF SOME PATHOGENIC BACTERIA ON THE SHEEP CARCASSES
}

\author{
Shimaa M. Abd El-Bar ${ }^{*}$ Yehia E. Ali ${ }^{* *}$,Nader Y. Moustafa ${ }^{* *}$ \\ and Azza Marghani M. Deeb ${ }^{* *}$ \\ ${ }^{*}$ B.V. Sc. Fac. of Vet. Med., Kafrelsheikh Univ., Egypt. \\ ** Food Control Dep., Fac. of Vet. Med., Kafrelsheikh Univ., Egypt.
}

\begin{abstract}
A total of 150 swabs were collected from El-Mahala El-Kobra abattoir, in El-Gharbia Governorate (Egypt) as follow; (50 from the outer surface of sheep carcasses after skinning, 50 from the inner surface of the same carcasses after evisceration and 50 from workers' hands). The samples were examined bacteriologically for staphylococci, coliforms and enterococci with percentages (96, 100 and 98\%), (50, 76 and 72\%) and (40, 60 and 68\%) for positive samples, respectively.
\end{abstract}

\section{INTRODUCTION}

Lamb is a very good source of protein, minerals and vitamins, which are necessary for human consumption. Unfortunately, due to this rich in composition, mutton is a favorable environment for the growth of bacteria which can survive, multiply and may produce toxins, result in public health hazard. The internal tissue of healthy animals is virtually 
sterile and bacterial contamination only occurs during slaughter, dressing, handling and storage (Nortje et al., 1990).

As soon as muscle tissue is exposed, it may be contaminated by pathogens and deteriorative bacteria from the hide's normal microbes. The contamination of these tissues with microorganisms after slaughter is undesirable but unavoidable consequence of this process by which live animals are converted into meat for human consumption (Ayres, 1955).

Hides, hooves and hair not only contain large numbers of microorganisms from soil, manure, feed and water but also important kinds of spoilage organisms so, they are considered the most important sources of microbial contamination on flayed carcasses. So contact between the carcass and the skin, including the fleece in the case of sheep and lambs, allows contamination with a mixture of microorganisms derived from the animal's pre-slaughter environment, including those of faecal, soil, water and feed origin (Bell and Hathaway, 1996).

Other sources of potential contamination in abattoirs include equipments, operatives' clothing and hands, air, water, walls and doors (Sierra et al., 1995).

Therefore the goal of the present study was to recognize the level of microbial contamination on mutton carcasses and to throw the light on the sources of their contamination in an attempt to produce mutton of high quality. 


\section{MATERIALS AND METHODS}

\section{Collection of samples:}

A total of (150) swabs were collected from El-Mahala El-Kobra abattoir, in El-Gharbia Governorate (Egypt) as follow; (50 from the outer surface of sheep carcasses after skinning, 50 from the inner surface of the same carcasses after evisceration and 50 from workers' hands) in one direction in an area of $100 \mathrm{Cm}^{2}$ using a template made from stainless steel in sterile test tubes containing $0.1 \%$ peptone water.

The swabs samples were transferred in an ice box under possible aseptic condition to the laboratory, where they were examined bacteriologically.

\section{Preparation of samples:}

From the original swabs specimen tenth fold serial dilutions were done and subjected to bacteriological examination according to (Williams et al., 1983).

\section{Bacteriological examination:}

- Total staphylococci count according to (ICMSF, 1996), isolation and identification of suspected Staphylococcus aureus strains according to (APHA, 2001).

- Total coliforms count (MPN/Cm²) according to (ICMSF, 1996), isolation and identification of coliform organisms according to (FDA, 1998).

- Total enterococci count according to (Mossel et al., 1978), isolation and identification of enterococci according to (Quinn et al., 1994). 


\section{RESULTS}

Table (1): Statistical analytical results of total staphylococci count $\left(\mathrm{CFU} / \mathrm{Cm}^{2}\right)$ of the examined samples $(n=50)$.

\begin{tabular}{|c|c|c|c|c|c|}
\hline \multirow{2}{*}{ Examined samples } & \multicolumn{2}{|c|}{ Positive samples } & \multicolumn{3}{|c|}{ Counts } \\
\hline & No. & $\%$ & Min. & Max. & Mean $\pm \mathrm{SE}$ \\
\hline $\begin{array}{l}\text { Outer surface of the } \\
\text { carcasses }\end{array}$ & 48 & 96 & $1 \times 10^{3}$ & $1.17 \times 10^{6}$ & $3.68 \times 10^{5} \pm 5.37 \times 10^{4}$ \\
\hline $\begin{array}{l}\text { Inner surface of the } \\
\text { carcasses }\end{array}$ & 50 & 100 & $1 \times 10^{3}$ & $1.02 \times 10^{6}$ & $3.57 \times 10^{5} \pm 4.13 \times 10^{4}$ \\
\hline Workers' hands & 49 & 98 & $1 \times 10^{3}$ & $1.39 \times 10^{6}$ & $4.70 \times 10^{5} \pm 5.47 \times 10^{4}$ \\
\hline
\end{tabular}

Table (2): Frequency distribution of the examined samples based on their total staphylococci count $\left(\mathrm{CFU} / \mathrm{Cm}^{2}\right)$.

\begin{tabular}{|c||c||c||c||}
\hline \multirow{2}{*}{ Intervals } & $\begin{array}{c}\text { Outer surface of the } \\
\text { carcasses }\end{array}$ & $\begin{array}{c}\text { Inner surface of the } \\
\text { carcasses }\end{array}$ & Workers' hands \\
\cline { 2 - 4 } & No. & No. & No. \\
\hline \hline$<10^{3}$ & 0 & 0 & 3 \\
\hline $10^{3}-<10^{4}$ & 2 & 4 & 8 \\
\hline $10^{4}-<10^{5}$ & 18 & 11 & 34 \\
\hline $10^{5}-<10^{6}$ & 23 & 34 & 4 \\
\hline $10^{6}-<10^{7}$ & 5 & 1 & $\mathbf{4 9}$ \\
\hline \hline Total & $\mathbf{4 8}$ & $\mathbf{5 0}$ & 0 \\
\hline
\end{tabular}

$\overline{\text { Kafrelsheikh Vet. Med. J. Vol. } 10 \text { No. } 1 \text { (2012) }}$ 
Occurrence Of Some Pathogenic Bacteria On ...

Table (3): Incidence of Staphylococcus aureus in the examined samples $(n=50)$.

\begin{tabular}{|c|c|c|c|c|}
\hline \multirow[t]{2}{*}{ Examined samples } & \multicolumn{2}{|c|}{$\begin{array}{c}\text { *Suspected } S \text {. aureus } \\
\text { positive samples }\end{array}$} & \multicolumn{2}{|c|}{$\begin{array}{c}* * \text { Coagulase positive } S . \\
\text { aureus samples }\end{array}$} \\
\hline & No. & $\% * * *$ & No & $\% * * *$ \\
\hline $\begin{array}{l}\text { Outer surface of the } \\
\text { carcasses }\end{array}$ & 8 & 16 & 5 & 10 \\
\hline $\begin{array}{l}\text { Inner surface of the } \\
\text { carcasses }\end{array}$ & 17 & 34 & 13 & 26 \\
\hline Workers' hands & 12 & 24 & 8 & 16 \\
\hline
\end{tabular}

* According to colony character on Baird parker agar medium.

** After biochemical identification.

*** From the total examined samples.

Table (4): Statistical analytical results of total coliforms count $\left(\mathrm{MPN} / \mathrm{Cm}^{2}\right)$ of the examined samples $(n=50)$.

\begin{tabular}{|c|c|c|c|c|c|}
\hline \multirow{2}{*}{$\begin{array}{c}\text { Examined } \\
\text { samples }\end{array}$} & \multicolumn{2}{|c|}{ Positive samples } & \multicolumn{3}{|c|}{ Counts } \\
\hline & No. & $\%$ & Min. & Max. & Mean $\pm \mathrm{SE}$ \\
\hline $\begin{array}{c}\text { Outer surface of the } \\
\text { carcasses }\end{array}$ & 25 & 50 & 3 & $2.4 \times 10^{4}$ & $1.04 \times 10^{3} \pm 9.58 \times 10^{2}$ \\
\hline $\begin{array}{c}\text { Inner surface of the } \\
\text { carcasses }\end{array}$ & 38 & 76 & 3.6 & $2.4 \times 10^{4}$ & $5.11 \times 10^{3} \pm 1.60 \times 10^{3}$ \\
\hline Workers' hands & 36 & 72 & 3 & $2.4 \times 10^{4}$ & $4.76 \times 10^{3} \pm 1.59 \times 10^{3}$ \\
\hline
\end{tabular}

$\overline{\text { Kafrelsheikh Vet. Med. J. Vol. } 10 \text { No. } 1 \text { (2012) }}$ 
Table (5): Frequency distribution of examined samples based on their total coliforms count (MPN/Cm²).

\begin{tabular}{||c||c||c||c||}
\hline \multirow{2}{*}{ Intervals } & $\begin{array}{c}\text { Outer surface of the } \\
\text { carcasses }\end{array}$ & $\begin{array}{c}\text { Inner surface of the } \\
\text { carcasses }\end{array}$ & Workers' hands \\
\cline { 2 - 4 } & No. & No. & No. \\
\hline \hline$<10$ & 13 & 13 & 14 \\
\hline $10-<10^{2}$ & 9 & 11 & 11 \\
\hline $10^{2}-<10^{3}$ & 1 & 6 & 2 \\
\hline $10^{3}-<10^{4}$ & 1 & 0 & 7 \\
\hline $10^{4}-<10^{5}$ & 1 & 8 & $\mathbf{3 6}$ \\
\hline \hline Total & $\mathbf{2 5}$ & $\mathbf{3 8}$ & 2 \\
\hline \hline
\end{tabular}

Table (6): Statistical analytical results of total enterococci count $\left(\mathrm{CFU} / \mathrm{Cm}^{2}\right)$ of the examined samples $(n=50)$.

\begin{tabular}{|c|c|c|c|c|c|}
\hline \multirow{2}{*}{ Examined samples } & \multicolumn{2}{|c|}{ Positive samples } & \multirow{2}{*}{ Min. } & \multirow{2}{*}{ Max. } & \multirow{2}{*}{ Mean \pm SE } \\
\hline & No. & $\%$ & & & \\
\hline $\begin{array}{c}\text { Outer surface of the } \\
\text { carcasses }\end{array}$ & 20 & 40 & $1 \times 10^{2}$ & $3.55 \times 10^{4}$ & $3.38 \times 10^{3} \pm 1.79 \times 10^{3}$ \\
\hline $\begin{array}{l}\text { Inner surface of the } \\
\text { carcasses }\end{array}$ & 30 & 60 & $1 \times 10^{2}$ & $6.15 \times 10^{4}$ & $5.95 \times 10^{3} \pm 2.09 \times 10^{3}$ \\
\hline Workers' hands & 34 & 68 & $1 \times 10^{2}$ & $5.76 \times 10^{4}$ & $7.61 \times 10^{3} \pm 2.36 \times 10^{3}$ \\
\hline
\end{tabular}

Kafrelsheikh Vet. Med. J. Vol. 10 No. 1 (2012) 
Occurrence Of Some Pathogenic Bacteria On ...

Table (7): Frequency distribution of examined samples based on their total enterococci count $\left(\mathrm{CFU} / \mathrm{Cm}^{2}\right)$.

\begin{tabular}{||c||c||c||c||}
\hline \multirow{2}{*}{ Intervals } & $\begin{array}{c}\text { Outer surface of the } \\
\text { carcasses }\end{array}$ & $\begin{array}{c}\text { Inner surface of the } \\
\text { carcasses }\end{array}$ & Workers' hands \\
\cline { 2 - 4 } & No. & No. & No. \\
\hline \hline$<10$ & 0 & 0 & 0 \\
\hline $10-<10^{2}$ & 0 & 0 & 11 \\
\hline $10^{2}-<10^{3}$ & 11 & 7 & 18 \\
\hline $10^{3}-<10^{4}$ & 7 & 19 & 5 \\
\hline $10^{4}-<10^{5}$ & 2 & $\mathbf{3 0}$ \\
\hline \hline Total & $\mathbf{2 0}$ & $\mathbf{3 4}$ \\
\hline
\end{tabular}

Table (8): Correlation between total staphylococci in workers' hands and their counts in the outer and inner surfaces of the carcasses.

\begin{tabular}{|c||c||c|}
\hline \multicolumn{2}{|c||}{ Examined swabs samples } & $\begin{array}{c}\text { Correlation } \\
\left(\mathbf{R}^{2} \text { values }\right)\end{array}$ \\
\hline \hline \multirow{2}{*}{ Workers' hands } & $\begin{array}{c}\text { Outer surface of the } \\
\text { carcasses }\end{array}$ & $.539^{* *}$ \\
\cline { 2 - 3 } & $\begin{array}{c}\text { Inner surface of the } \\
\text { carcasses }\end{array}$ & $.000)$ \\
$(\mathrm{P}=.050)$ \\
\hline
\end{tabular}

Kafrelsheikh Vet. Med. J. Vol. 10 No. 1 (2012) 


\section{DISCUSSION}

Results obtained in Table (1) revealed that 96, 100 and $98 \%$ of outer surface of the carcasses, inner surface of the carcasses and workers' hands swab samples were positive for staphylococci with counts $\left(\mathrm{CFU} / \mathrm{Cm}^{2}\right.$ ) ranged from $1 \times 10^{3}$ to $1.17 \times 10^{6}, 1 \times 10^{3}$ to $1.02 \times 10^{6}$ and $1 \mathrm{x}$ $10^{3}$ to $1.39 \times 10^{6}$ with mean values of $3.68 \times 10^{5} \pm 5.37 \times 10^{4}, 3.57 \times 10^{5} \pm$ $4.13 \times 10^{4}$ and $4.70 \times 10^{5} \pm 5.47 \times 10^{4}$, respectively. All examined positive samples of both outer and inner surfaces of the carcasses in (Table 2) were higher than the allowable limits of $<1000 / \mathrm{g}$ for staphylococci count in raw meat by Canadian Government Provisional Guideline "Wehr" (1982), also the highest frequency distributions 23,34 and 34 from the positive samples of outer surface of the carcasses, inner surface of the carcasses and workers' hands lied within the range of $10^{5}-<10^{6}$ $\mathrm{CFU} / \mathrm{Cm}^{2}$ and this proved that the outer surface of the carcasses, inner surface of the same carcasses and workers' hands were exposed to the same source of contamination. While Table (3) showed that 16, 34 and $24 \%$ of examined swab samples of outer surface of the carcasses, inner surface of the carcasses and workers' hands presumed to contain $S$. aureus according to colonial character on Baird parker medium and only the isolates of 10, 26 and $16 \%$ of these examined swab samples were identified as coagulase positive $S$. aureus.

The results presented in Table (4) revealed that 50, 76 and $72 \%$ of examined swab samples of outer surface of the carcasses, inner surface

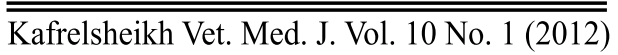


of the carcasses and workers' hands were positive for coliforms with counts (MPN/ $\mathrm{Cm}^{2}$ ) ranged from 3 to $2.4 \times 10^{4}, 3.6$ to $2.4 \times 10^{4}$ and 3 to $2.4 \times 10^{4}$ with mean values of $1.04 \times 10^{3} \pm 9.58 \times 10^{2}, 5.11 \times 10^{3} \pm 1.60 \times$ $10^{3}$ and $4.76 \times 10^{3} \pm 1.59 \times 10^{3}$, respectively. Although 2 and 8 from the positive samples of both outer and inner surfaces of the carcasses were exceeding the maximum allowable limit $10^{3}$ and $10^{4} \mathrm{CFU} / \mathrm{g}$ for coliforms in raw meat by Canadian Food Inspection Agency (2003) and CODEX CAC/RCP-8 (2008), but the highest frequency distribution 13 from both outer and inner surfaces positive samples of the carcasses lied within the range of $<10 \mathrm{MPN} / \mathrm{Cm}^{2}$. While the highest frequency distribution 14 from the positive samples of workers' hands lied at the same range of $<10 \mathrm{MPN} / \mathrm{Cm}^{2}$ (Table 5).

The results presented in Table (6) revealed that 40, 60 and $68 \%$ of examined swabs samples of outer surface of the carcasses, inner surface of the carcasses and workers' hands were positive for enterococci with counts $\left(\mathrm{CFU} / \mathrm{Cm}^{2}\right)$ ranged from $1 \times 10^{2}$ to $3.55 \times 10^{4}, 1 \times 10^{2}$ to $6.15 \mathrm{x}$ $10^{4}$ and $1 \times 10^{2}$ to $5.76 \times 10^{4}$ with mean values of $3.38 \times 10^{3} \pm 1.79 \times 10^{3}$, $5.95 \times 10^{3} \pm 2.09 \times 10^{3}$ and $7.61 \times 10^{3} \pm 2.36 \times 10^{3}$, respectively. The results in (Table7) showed that the highest frequency distribution 11 from the positive samples of the outer surface of the carcasses lied within the range of $10^{2}-<10^{3} \mathrm{CFU} / \mathrm{Cm}^{2}$. While the highest frequency distributions 19 and 18 from the positive samples of both inner surface of the carcasses and workers' hands lied within the range $10^{3}-<10^{4}$ $\mathrm{CFU} / \mathrm{Cm}^{2}$. 
From the results in Table (8) it was evident that there was highly significant positive correlation $(\mathrm{p}<0.01)$ between staphylococci count in the workers' hands and their count in the outer surface of the carcasses, also there was a significant positive correlation $(\mathrm{p}<0.05)$ between staphylococci count in the workers' hands and their count in the inner surface of the carcasses as human skin, nose and nails are the main sources of staphylococci (Postgate, 2000).

From the previous results the higher incidence of microbial load in this study might be attributed to unhygienic and improper handling of animals during slaughter, dressing and evisceration. Also, the results of high faecal coliforms and enterococci contamination in this study reflect failing manipulations particularly during evisceration, unhygienic workers' behaviours, direct contact with skin and faeces, and the use of tools contaminated by faeces present at the slaughtering halls. In addition to, the usual incorrect practice of washing the carcass with the same water in which intestines and offal had been washed. Therefore, hygienic handling, intermittent microbial analysis and constant monitoring are necessary to produce hygienic and wholesome meat to ensure safe public health.

\section{REFERNCES}

- APHA (American Public Health Association) (2001): Compendium of methods for the microbiological examination of foods. 4th ed. Washington, D.C. 
- Ayres, J.C. (1955): Microbiological implications in the handling, slaughter and dressing of meat animals. Advanced Food Res. 6:109-161.

- Bell, R.G. and Hathaway, S.C. (1996): The hygienic efficiency of conventional and inverted lamb dressing systems. J. Appl. Bacteriol., 81(3):225-234.

- Canadian Food Inspection Agency (2003): Meat Hygiene Manual of Procedures, Sampling and Testing Procedures; Available from: http://www.inspection.gc.ca/english/animal/meavia/mmopmmhv/table 5e.shtml.

- Canadian Government Provisional Guideline "Wehr" H.M. (1982): Attitudes and Policies of governmental agencies on microbial criteria for foods- An update. Food Technol. 36(9): 45-54.

- CODEX CAC/RCP 8 - (2008): "Recommended International Code of Practice for the Processing and Handling of Quick Frozen Foods”.

- F.D.A. (Food and Drug Administration) (1998): Bacteriological analytical manual 8th Edition, AOAC international, Gaithersburg, USA.

- ICMSF (International Commission on Microbiological Specification for Foods) (1996): Microorganisms in food Ш: Microbial Specification of Food pathogens. Vol. 2 Chapman and Hall, London, New York. 
- Mossel, D.D.A.; Bijker, P.G.H. and Eelderink, I. (1978): Streptokokken der Lancefield-Gruppe D in Lebensmitteln und Trinkwasser - Ihre Bedeutung, Erfassung und Bekampfung. - Arch. f. Lebensmittelhyg., 29: 121-127.

- Nortje, G.L.; Nel, L.; Jordaan, E.; Badenhorst, K.; Goedhart, G.; Holzapfel, W.H. and Grimbeek, R.J. (1990): A quantitative survey of a meat production chain to determine the microbial profile of the final product. J. Food Prot. 53(5): 411-417.

- Postgate, J.R. (2000): Microbes and man. Oxford, UK; New York: Cambridge University Press. Pp 373.

- Quinn, P.J.; Carter, M.E.; Markey, B.K. and Carter, G.R. (1994): Streptococci and related cocci. In: Clinical Veterinary Microbiology, Wolfe Publishing Mosby-Year. Book Limited, London, pp: 127-136.

- Sierra, M. L.; Gonzalez-Fandos, E.; Garcia-Lopez, M. L.; GarciaFernandez, M.C. and Morena, B. (1995): Contamination of lamb carcasses at the abattoir. Microflora of the freshly dressed lamb carcasses: indicators and spoilage organisms. Archiv für lebensmittelhygiene, Alfeld, 46(6): 135-137.

- Williams, R.P.; Farmur, C.W.; Moohipark, L.A. and Wehr, H.M. (1983): Bacteriological evaluation of meat processor sanitation practices. J. Food Prot. 46(7): 605-609. 


\section{تو اجد بعض البكتيريا المسببة للأمر اض على ذبائح الأغنام}

نظرا لأهمية لحوم الضأن فقد أجريت هذه الدراسة على بعض ذبائح الأغنام بمجزر المحلة الكبرى بمحافظة الغربية وذلك للتعرف على مدى درجة تلوثها ببعض البكتيريا المسببة للأمراض داخل المجزر. لذا فقد نم تجميع عدد 150 مسحة وكانت المسحات شاملة 50 مسحة من كل من السطح الخارجي لذبائح الأغنام و 50 أخرى من سطحها الداخلي وأيضا 50 مسحة من أيدي القائمين بعملية الذبح. وقد أسفرت النتائج أن نسبة كل من الميكروبات العنقودية ,الميكروبات القولونية والميكروبات السبحية المعوية في العينات الموجبة لكل من السطح الخارجي للابائح, السطح الداخلي لنفس الذبائح و أيدي القائمين بعطية الذبح هي (96,\%0\% و \%8\%) , (50\%, 76\% و72\%) و (40\% , \%60 و \% \% \%

كما لوحظ أيضا وجود علاقة إرتباط طردية ذات فروق معنوية بين تواجد الميكروبات العنقودية في أيدي العاملين بالمجزر وتأثير ذلك على نواجدهم في الذبائح وهذا يثبت بالتأكيد أن القائمين بالعمل داخل المزر لا يتبعون الأساليب الصحية السليمة في ارتداء ملابس نظيفة ولا يقومون بغسل أيديهم أثثاء المراحل المختلفة لتجهيز الذبائح.

هذا وقد نوقشت الأسباب المختلفة لتلوث تلك الذبائح داخل المجزر وأيضا الدور الذي تلعبه الميكروبات السابقة في ذلك مع الإشارة إلى الحد المسموح به لبعض هذه الميكروبات طبقا للمنظمات العالمية وذلك للوصول في النهاية لذبائح سليمة ومن ثم لحوم ذات كفاءة عالية خالية من الأمراض لضمان سلامة المسترلك. 